Relations industrielles

Industrial Relations

\title{
New Conception of Industrial Relations Research
}

\section{Emile Gosselin}

Volume 7, numéro 1-2, décembre 1951, mars 1952

URI : https://id.erudit.org/iderudit/1023117ar

DOI : https://doi.org/10.7202/1023117ar

Aller au sommaire du numéro

Éditeur(s)

Département des relations industrielles de l’Université Laval

ISSN

0034-379X (imprimé)

1703-8138 (numérique)

Découvrir la revue

Citer cet article

Gosselin, E. (1951). New Conception of Industrial Relations Research. Relations industrielles / Industrial Relations, 7(1-2), 110-113.

https://doi.org/10.7202/1023117ar
Résumé de l'article

Following the study of a publication of the University of Minnesota, the author analyses the contents of the document dealing with a new conception of research in industrial relations.
Tous droits réservés (C) Département des relations industrielles de l’Université Laval, 1952
Ce document est protégé par la loi sur le droit d'auteur. L'utilisation des services d'Érudit (y compris la reproduction) est assujettie à sa politique d'utilisation que vous pouvez consulter en ligne.

https://apropos.erudit.org/fr/usagers/politique-dutilisation/ 


\title{
New Conception of Industrial Relations Research
}

\author{
Emile Gosselin
}

Following the study of a publication of the University of Minnesota, the author analyses the contents of the document dealing with a new conception of research in industrial relations.

The Industrial Relations Center of the University of Minnesota, following studies undertaken in industrial relations reseach, has just published "Triple Audit of Industrial Relations". ${ }^{1}$ This bulletin is not only for those persons already specialized in research work. Employers, labour leaders, government employees, members of the clergy, scholars will find many new aspects on activities relating to production. After reading this document, it may perhaps be asked, if the solutions that are now applied to labour problems as well as the theories advanced on the subject are always derived from true industrial reality and are really related to the needs of man as an entity.

The authors propose the method of Triple Audit as a way of giving a new and highly scientific impetus to industrial relations research. In the first part of the document, they establish the concepts of industrial relations and of research in this sector where all social sciences meet. The Triple Audit would be an answer to the requirements of the analysis and the solution of labour problems. It would also appear to be a method of obtaining a progressive and regulated increase in our knowledge in this sphere.

The promising results obtained following the application of the Triple Audit of industrial relations in a certain number of enterprises opens up so many avenues for new research work. The hypothesis raised by the data gathered will bring about many questions in particular among labour leaders and employers.

(1) Triple Audit of Industrial Relations by Dale Yoder, Herbert G. Heneman, Jr. and Earl F. Chert, Bulletin 11, August 1951, Industrial Relations Center, University of Minnesota Press, Minneapolis.
GOSSELIN EMILE, Master of Law (Montreal), M.A. in Economics (Toronto), Secretary of the Industrial Relations Department of Laval University, in charge of the course of Economics of Labour and Director of industrial relations research. 
We shall limit this article to a brief list of the motives which led to the development of this new method of analyzing industrial relations. We believe that the principles brought out are of a nature to provoke profound changes in the methodology of industrial relations.

The Triple Audit of industrial relations is so called because at the beginning it was proposed to audit three types of fundamental factors in industrial relations simultaneously: 1) relevant policies and practices of individual employers, unions and public agencies; 2) economic characteristics of employers; 3 ) employee reactions or behavior. Methods of quantitative analysis permit the comparison of these factors or fundamental phases to established norms recognized by all; it then became possible to note apparently consistent interrelationships.

This new direction given research requires as the first condition that the factors identified will be treated as quantities. This "quantitative" method of procedure uses sociometric analysis and permits us to identify the factors involved, to measure them, to make comparisons between them, to set up a kind of scale to measure quantitatively the relationships. "...The Triple Audit proceeds on the dual assumption that such relationships can be appraised more readily if factors are quantified and measured and that factors can be stated in quantitative terms. It is apparent that factors of the types generally noted seldom appear as absolutes, being either present or absent. Productivity, morale, in-plant communication, union recognition and acceptance - all illustrate this point. They appear in varying degrees. Differences in their degrees are assumed to create the significant variables in functional relationships of factors and industrial relations behavior. Measurement of these degrees is, therefore, an essential to accurate, realistic description of significant relationships." 2

The authors adopt the system of quantitative measurements because research on relationships between different factors is likely to give us the most possible knowledge of industrial relationships. It is therefore important to discover, by acoumulating facts, to what extent certain determined types of behavior may be associated in a significant way to certain identifiable factors.

This viewpoint of industrial relations research implies essentially the coparticipation of all the social disciplines. "...The Triple Audit assumes that employment is much more than merely the economic allocation of manpower, that employment also creates the setting for numerous psychological, sociological, political, and other processes. Hence, explanation of the behavior in question can be most meaningful and useful if analysis is planned and conducted by a research team that employs the know-how and the viewpoints of several social disciplines. In other words, the Triple Audit approach is essen-

(2) Ibid. p. 11. 
tially and basically intendisciplinary or - perhaps better - coidisciplinary, i.e., involving joint analysis by several social disciplines." ${ }^{3}$

Labour problems do not constitute in themselves new subjects of research for the various specialists in each discipline or social science. For many years, economists, sociologists, psychologists and many others have considered at length certain problems concerning as much the distribution as the use of human resources. But "they have recognized no special area of industrial relations. They have approached the human behavior growing ont of employment as merely a portion of the broader area of individual or group activity their disciplines sought to describe." 4 At the beginning, each discipline was not prepared enough or inclined to co-ordinate its own reseach with that of other disciplines. There was no agreement on the concepts or hypothesis of work or on the methods and techniques.

If the efforts of each discipline are not grouped in a general frame of reference, if a choice is not made among hypotheses, if the concepts are vague and badly identified, if there does not exist a common scale of measurement, it becomes more and more difficult to verify with facts the various theories resulting from separate efforts. In partioular, it is almost impossible to compare with each other these various results. Therefore how may we determine if each research constitutes progress from the previous work ? Does all this work undertaken by each discipline and quite often ignored by the others constitute a real increase in the knowledge of labour relations? Because of all these obstacles, the authors conclude that a new stage must be reached in research where each study, particular or common, enters into a general design. We could thus eventually develop one or several theories of industrial relations. Would the Triple Audit of industrial relations be a proper way to reach this result? "Its principal distinctions may be described briefly as follows: 1) it uses a co-disciplinary attack in both the design of studies and the analysis of data;2) it stresses the desirability of quantification or measurement; 3) it seeks to describe facts and relationships in industrial relations on the basis of empirical study; and 4) it points to the importance of accumulating small, segmental studies that can be additive in building understanding of the behavior that characterizes employment relationships." 5

One could no doubt discuss the premises that the bulletin gives to research. We believe that it will have for effect to initiate a movement directed towards a more comprehensive explanation of all the factors acting simultaneously in the allocation and utilization of human resources. Similar methods will perhaps bring us closer to the day when it will be possible to explain with the aid of all of the social sciences, how man is affected by employment, because the allocation and utilization of human resources implies factors which go

(3) Ibid. p. 10.

(4) Ibid. p. 4.

(5) Ibid. p. iii. 
beyond the strictly economic sphere. The solution to many social, family and religious problems will depend to a great extent on the answers that will be given to the questions raised by labour.

For a really efficient research in this field, it will be necessary to insure, in addition to the cooperation already acquired of all the social disciplines, that of all the persons interested in the study of industrial relations problems.

WAGES AND PRICES

$7^{\text {th }}$ Industrial Relations Canvention

CHATEAU FRONTENAC, QUEBEC

Monday and Tuesday, April 21st and 22nd 1952

\section{Pragramene}

Monday, April 21st

Morning

9.00 Registration.

9.30 Speeches of Mgr. Ferdinand Vandry, P.A., V.G., Rector of Laval University, and of Mr. Gerard Tremblay, Deputy Minister of Labour of the Province of Quebec and Director of the Department of Industrial Relations of Laval.

10.15 Inflation: nature, causes and kinds.

\section{Afternoon}

2.30 Effects of inflation on wages, prices and profits.

4.00 The unions' position towards inflation and their programme of action.

4.30 The employers' position towards inflation and their programme of action.
Tuesday, April 22nd

Morning

9.00 Basing wages on the cost of living. Adjustment by negotiation and arbitration or by escalator provision.

10.30 Wages varying with productivity. Nature and effects of this adjustment.

\section{Afternoon}

2.30 Voluntary arbitration of prices and wages. Nature of this voluntary arbitration and its effects in period of employment.

4.00 State control of prices and wages. Nature and effects of such a control.

7.00 Closing banquet: Ball-room of the Chateau Frontenac. Guest Speaker.

REGISTRATION: The registration fee is fifteen dollars and includes the attendance at the conferences and forums and closing banquet as well as the right to a complete report of the Convention. Because of the necessity to limit the number of delegates, it is recommended that reservations be made as soon as possible to the Department of Industrial Relations, 2, rue de l'Université, Quebec. (tel: 2-3951). The speeches will be given in French. 